\title{
Joanna Buława-Halasz
}

Uniwersytet Szczeciński

\section{Przemoc symboliczna w rehabilitacji osób autystycznych}

STRESZCZENIE Artykuł jest próbą reinterpretacji kategorii przemocy symbolicznej w odniesieniu do rehabilitacji osób autystycznych propozycją teoretyczną w badaniu tego procesu. Niniejsze opracowanie jest próbą sięgnięcia do ukrytych mechanizmów tworzących bądź podtrzymujących dyskryminację (marginalizację lub wykluczenie) osób autystycznych. Dyskryminacja osób autystycznych przejawia się na poziomie interpersonalnym, instytucjonalnym, kulturowym. Jest mocno związana z opresyjnym przekonaniem o konieczności podporządkowania się niepełnosprawnych osobom „typowym” (pełnosprawnym). Tak jak osoby pełnosprawne zachowują się w sposób „opresyjny” wobec niepełnosprawnych (nie zawsze z pełną świadomością), tak samo terapeuci w swoich oddziaływaniach rehabilitacyjnych (pedagogiczno-terapeutycznych) stosują przemoc symboliczną wobec osób autystycznych, które z racji specyfiki całościowych zaburzeń rozwoju są szczególnie na nią narażone.
SŁOWA KLUCZOWE AUTYZM, REHABILITACJA, PRZEMOC SYMBOLICZNA 
Niniejsze opracowanie jest próbą sięgnięcia do ukrytych mechanizmów tworzących bądź podtrzymujących dyskryminację (marginalizację lub wykluczenie) osób autystycznych. Wykluczenie osób autystycznych, czy szerzej osób niepełnosprawnych, przejawia się na trzech płaszczyznach: interpersonalnej, instytucjonalnej i kulturowej. Jest mocno związane z opresyjnym przekonaniem o konieczności podporządkowania się osobom pełnosprawnym. Tak jak osoby pełnosprawne zachowują się w sposób „opresyjny” wobec niepełnosprawnych (nie zawsze z pełną świadomością), tak samo terapeuci w swoich działaniach rehabilitacyjnych (pedagogiczno-terapeutycznych) stosują przemoc symboliczną wobec osób autystycznych, które z racji całościowych zaburzeń rozwoju są szczególnie na nią narażone.

W praktyce pedagogiczno-terapeutycznej bardzo długo obowiązywał tylko biomedyczny (indywidualny) model niepełnosprawności, w którym problemy, z jakimi borykają się osoby z niepełnosprawnością, są konsekwencją choroby czy kalectwa (Źółkowska 2004: 34). Zbigniew Woźniak (2008: 68-69) definiuje niepełnosprawność jako

odchylenie od biomedycznych norm oraz standardów struktury i/lub funkcji organizmu. Jednostka jest postrzegana przez pryzmat choroby czy czynnika uszkadzającego, powodującego niepełnosprawność, którą przy wykorzystaniu szerokiego instrumentarium leczniczo-rehabilitacyjnego powinno się dostosować do warunków, w jakich żyją osoby pełnosprawne. Takie jednostronne podejście może prowadzić do dyskryminacji i stygmatyzacji osoby niepełnosprawnej.

U podstaw realizacji tego modelu leżą przekonania i sądy wartościujące, które mówią, co jest odpowiednie dla niepełnosprawnych, a każde odstępstwo od tych ustaleń jest traktowane jako niepowodzenie procesu adaptacji (Źółkowska 2004: 34).

W latach siedemdziesiątych XX wieku po raz pierwszy krytyka „pełnosprawnego” społeczeństwa została wpisana, w odmienny od biomedycznego, model niepełnosprawności (Barnes, Mercer 2008: 18). Społeczny model niepełnosprawności wskazuje na ograniczające środowisko i bariery społeczne, ekonomiczne i fizyczne, a nie poszukuje się ich w jednostce (Wapiennik, Piotrowicz 2002: 20-21). W praktyce chodzi więc o to, by nie przystosowywać jednostki do społeczeństwa (jak to się działo w modelu indywidualnym), ale zastanowić się, czy i na ile to społeczeństwo może zmienić swoje wzorce i normy do możliwości osób niepełnosprawnych (Żółkowska 2004: 34).

Każdy model jednostronny jest skazany w którymś momencie na krytykę. Idealny zakłada wszystkie aspekty składające się na niepełnosprawność: osobowe (uszkodzenia, deficyty, cechy osobnicze), środowiskowe (bariery fizyczne i społeczne), kulturowe (normy, zwyczaje), ekonomiczne (nakłady budżetowe na świadczenia społeczne, aktywność zawodowa) oraz polityczne (polityka społeczna) (Woźniak 2008: 82). Taki model jest podstawą do podjęcia rehabilitacji osób niepełnosprawnych (również autystycznych) rozumianej jako

zespół działań, w szczególności organizacyjnych, leczniczych, psychologicznych, technicznych, szkoleniowych, edukacyjnych i społecznych, zmierzających do osiągnięcia, przy aktywnym uczestnictwie tych osób, możliwie najwyższego poziomu ich funkcjonowania, jakości życia i integracji społecznej (Ustawa... art. 7, pkt I).

Mówiąc o rehabilitacji trzeba zadać pytanie - kim jest terapeuta osób autystycznych? Wykształcenie się specjalności terapeuty osób autystycznych (z jej szczególnym charakterem) na wzór dziedzin z wieloletnią tradycją, takich jak chociażby oligofrenopedagog, surdopedagog czy tyflopedagog (Zawody regulowane...), w literaturze pedagogiki specjalnej 
nie jest obecnie możliwe. Praktyka i teoria pedagogiczna zdołały bowiem określić podmiotowo oraz przedmiotowo specyfikę kwalifikacji i kompetencji tych specjalistów, a także wspólne i odrębne płaszczyzny działania. Nowo pojawiające się specjalności dopiero szukają swojej formuły. Tak jest również z terapeutą pedagogicznym, który wywodzi się z równie ogólnego pojęcia „terapia pedagogiczna”, funkcjonującego w różnych działach pedagogiki specjalnej. Każdy z nich, na własny użytek, profiluje i konkretyzuje treści działań terapeutycznych, a także kompetencje terapeutów pedagogicznych (Jastrząb, Baczała 2011: 99-100).

Trudno jednoznacznie określić, jaka powinna być specjalność pedagoga pracującego z osobami autystycznymi, ponieważ wśród nich są osoby niepełnosprawne intelektualnie wraz z dodatkowymi deficytami sprzężonymi, ponadto nie ma jednoznacznego określenia etiologii autyzmu, a co za tym idzie, opracowanej specyficznej terapii i określonego kanonu działań terapeutycznych (Gałkowski 2008: 14; Pisula 2008: 13-23). Praktyka pokazuje, że najczęściej terapeutami są pedagodzy specjalni bądź oligofrenopedagodzy. Terapia osób autystycznych należy natomiast do specjalności związanych z pełnieniem pomocy osobom niepełnosprawnym. Analizy specyfiki tej kategorii dokonała Joanna Kossewska (2014).

Autorka przytoczyła między innymi badania przeprowadzone wśród osób związanych z niesieniem pomocy osobom niepełnosprawnym: nauczycieli, pracowników służby zdrowia oraz rodziców i rodzeństwa. Wyniki pokazały, że lekarze, pielęgniarki czy rehabilitanci przypisują osobom niepełnosprawnym, którym pomagają, niski status społeczny. Ponadto, profesjonaliści w takim samym stopniu jak inni ludzie, czują się zagubieni, gdy muszą pracować z osobą niepełnosprawną, choć z założenia pracownicy zawodów pomocnych powinni być bardziej wrażliwi na potrzeby niepełnosprawnych. Inne badania pokazały, że psychologowie przejawiają względnie pozytywne postawy wobec dzieci niepełnosprawnych, ale różnią się one w zależności od stopnia i rodzaju niepełnosprawności dziecka okazują większą akceptację dzieciom z zaburzeniami o charakterze psychoedukacyjnym i funkcjonalnym niż dzieciom z zaburzeniami organicznymi i sensomotorycznymi, być może ze względu na możliwości i efekty pracy korekcyjnej. Psychologowie bardziej pozytywnie nastawieni są wobec dzieci chorych na AIDS i choroby przewlekłe oraz pacjentów z zaburzeniami sensorycznymi oraz trudnościami w uczeniu się niż wobec dzieci zaniedbanych, uzależnionych od środków odurzających, alkoholu, przejawiających zaburzenia łaknienia (anoreksja/bulimia), psychotycznych, autystycznych i z nadpobudliwością psychoruchową. Co ciekawe, ten sam profil postaw utrzymywał się wśród badanych psychologów niezależnie od zakresu osobistego kontaktu z dzieckiem niepełnosprawnym (w społeczności lokalnej, szkole, grupie rówieśniczej czy domu rodzinnym). Zachowania nauczycieli wobec niepełnosprawnych uczniów wpływają nie tylko na przystosowanie społeczne uczniów, ale także na efekty rehabilitacji. Wyniki badań wskazują, że nauczyciele szkół podstawowych prezentują nieprzychylne postawy wobec uczniów niepełnosprawnych, szczególnie wobec dzieci z porażeniem mózgowym i zaburzeniami emocjonalnymi. Istotną zmienną w kształtowaniu postaw nauczycieli wobec niepełnosprawnych wychowanków jest kontakt i własne doświadczenie - ci, którzy podejmują osobiste kontakty z dziećmi niepełnoprawnymi i ich rodzinami, charakteryzują się bardziej pozytywnymi postawami niż nauczyciele, którzy takich relacji nie utrzymują (Kossewska 2014).

Autyzm jest „superniepełnosprawnością”, na którą składają się: fizyczna niepełnosprawność, zamknięcie się w sobie, dystans do otaczającej rzeczywistości, problemy z komunikacją, napady lęków, agresja i inne problemy behawioralne (Thomassin 2004: 39). Kryteria diagnostyczne ujęte w klasyfikacjach ICD-10 (2008) i DSM-V wskazują przede wszystkim na występujące w autyzmie odchylenia od normy w interakcjach społecznych 
i komunikacji oraz ograniczony, sztywny i stereotypowy repertuar zachowań, zainteresowań, a także aktywności (Pisula 2005: 73; Jaklewicz 1993: 65-67; Frith 2008: 29-31, 127-147). Wszystkie powyższe odchylenia mogą występować w różnych kombinacjach i nasileniu.

Wraz z odchyleniami często współwystępuje niepełnosprawność intelektualna, jednak wśród badaczy nie ma zgodności co do tego, jaki odsetek osób autystycznych jest jednocześnie niepełnosprawnych fizycznie i intelektualnie, ponieważ w przypadku tej kategorii społecznej w ogóle nie można zbadać ilorazu inteligencji albo wykonane badanie pozostawia wiele wątpliwości. Wynikają stąd rozbieżności w procentowym rozkładzie poziomu rozwoju intelektualnego. Większość publikacji podaje, że około 75\% osób autystycznych jest niepełnosprawnych intelektualnie, 5\% stanowią „autystyczni geniusze” - niezwykle uzdolnieni, a pozostałe 20\% osób ma przynajmniej przeciętny poziom inteligencji (Smith 2009: 278; Frith 2008: 168; Pisula 2005: 50). Na podstawie powyższych danych mówi się o osobach nisko funkcjonujących jako tych z niepełnosprawnością intelektualną i wysoko funkcjonujących - pozostających w normie intelektualnej (Smith 2009: 278).

Osoby autystyczne mogą mieć także inne zaburzenia i choroby: padaczkę, słabą koordynację ruchową (Frith 2008: 221), nadpobudliwość psychoruchową czy dyspraksję, czasami również zachowania trudne, czyli takie, które swoim natężeniem, częstotliwością występowania lub długością trwania zagrażają bezpieczeństwu chorego bądź osobom w jego otoczeniu, albo takie, które uniemożliwiają nabywanie wiedzy, umiejętności lub zaspokajanie potrzeb życiowych (Proaktywne kierowanie trudnymi zachowaniami... 2004: 41-55).

Definicję zachowań trudnych, która podkreśla znaczenie oczekiwań społecznych i kulturowych oraz czynników środowiskowych proponuje Eric Emerson:

zachowanie kulturowo anormalne, o takim nasileniu, częstotliwości lub czasie trwania, iż fizyczne bezpieczeństwo osoby angażującej się w nie lub osób postronnych może być poważnie zagrożone, lub zachowanie, które może ograniczać możliwości korzystania ze zwykłych miejsc i instytucji użyteczności publicznej [ang. community facilities - dop. J.B.-H.] lub może skutkować odmową dostępu do nich (Emerson za: Kozłowski 2008: 99).

Osoby autystyczne w Polsce są „obywatelami niewidzialnymi”, spychanymi na margines życia społecznego. Brakuje działań podejmowanych przez jednostki samorządu terytorialnego i władze państwowe na rzecz poprawy sytuacji dorosłych osób autystycznych; nie są podejmowane kroki zmierzające do zmniejszenia ich dyskryminacji. Większość działań podejmowanych jest przez organizacje pozarządowe, działające w warunkach braku stabilności finansowej, na zasadach krótkookresowych projektów, utrudniających znacznie lub uniemożliwiających prowadzenie planowej działalności (Raport... 2013).

Przytoczone powyżej badania oraz Raport - na poziomie empirycznym - pokazują, że w istotnych przejawach życia, osoby autystyczne mogą być (ze względu na swą niepełnosprawność) uważane za ludzi w gorszym położeniu niż inni uczestnicy życia społecznego. Można również dowieść, że niekorzystne położenie osób autystycznych jest dialektycznie związane z ideologią lub ideologiami, które je uzasadniają i utrwalają. Poza tym „można postawić tezę, że taka niekorzystna sytuacja, jak i wspierająca ją ideologia, nie jest rzeczą naturalną ani konieczną. Wreszcie, należałoby ustalić, kto na tym stanie rzeczy korzysta" (Abberley za: Barnes, Mercer 2008: 32).

Autorzy Raportu pokazują, że dyskryminacja osób autystycznych przejawia się w praktykach wykluczenia na poziomie instytucjonalnym, bazują jednak na łatwo weryfikowalnych danych. Dużo trudniej jest dotrzeć do materiałów na poziomie interpersonalnym, 
kulturowym i społecznym. I taką kategorią „ukrytą”, która czeka na „odkrycie”, jest właśnie przemoc symboliczna.

Nieświadoma forma jest o tyle niebezpieczna, że nie uważa się jej za przemoc, choć potrafi nieść ze sobą realne konsekwencje, ponieważ „symbolicznymi środkami legitymizuje się (...), wzmacnia i utrwala przemoc realną, a zatem dodaje do niej swoiste, czysto symboliczne zniewolenie w sferze wartości” (Kłoskowska 1990: 17). Pierre Bourdieu (2004: 46-47) przestrzega przed nieodpowiednim rozumieniem określenia „symboliczna”:

Jedno z najczęstszych nieporozumień polega na akcentowaniu efektów czysto symbolicznych, czyli rzeczywistych skutków przemocy symbolicznej, co siłą rzeczy prowadzi do minimalizowania znaczenia aktów przemocy fizycznej: bicia, gwałtów, eksploatacji kobiet, lub gorzej, rozgrzeszania mężczyzn stosujących te formy przemocy, co nigdy nie było moim zamiarem. Ujmując „symboliczne” w opozycji do „realnego”, zakładalibyśmy, że przemoc symboliczna jest pozbawioną wymiaru realności przemocą czysto „duchową". (...) Chodzi więc o ukazanie obiektywnego wymiaru subiektywnego doświadczania dominacji.”.

Idąc dalej, Bourdieu zauważa, że

jeszcze bardziej zadziwiające jest to, że istniejący porządek z wpisanymi weń relacjami dominacji, prawami i krzywdą, przywilejami i niesprawiedliwością utrwala się łatwo (...), że trudne warunki egzystencji traktowane są jako akceptowalne, a nawet naturalne (2004: 7).

Aktorzy, ulokowani w jednorodnych warunkach egzystencji, narzucających jednorodne uwarunkowania i produkujących jednorodne systemy dyspozycji, dążą do wytwarzania podobnych praktyk. Działania, jakie podejmują aktorzy, są zależne od tego, na jakim polu (wyposażonym w konkretną logikę i przez to narzucającym różne formy realizacji) działają, ale również od tego, w jakiego typu zespół cech wspólnych - będących właściwościami zobiektywizowanymi, czasem zagwarantowanych prawnie (posiadane dobra, władza), a niekiedy ucieleśnionych (habitusy klasowe) - są oni dodatkowo wyposażeni (Bourdieu 2005: 132).

Habitus terapeutów to ich dyspozycje do określonego spostrzegania i oceniania, które są słuszne i sensowne w ramach obowiązującej wizji świata; to umiejętności działania praktycznego, społecznie nabyta kompetencja, na podstawie której terapeuta dokonuje poznawczego, emocjonalnego uzewnętrznienia określonej wersji rzeczywistości, ale też znajduje miejsce oraz możliwość działania w istniejącym układzie społecznym. Habitus to również struktura poznawcza, motywacyjna, kierująca działaniem terapeutów. Nie można zapominać, że jest to także warunek skuteczności przemocy symbolicznej, która prowadzi do eliminacji innych sposobów definiowania świata oraz redukuje wieloznaczność świata społecznego - sprowadza ją do świata ludzi „typowych”.

Na podstawie przedstawionych powyżej badań oraz teorii społecznej Bourdieu można przyjąć, że terapeuci - jako podmioty społeczne - przyjmują świat z jego regułami, które są zrozumiałe. Rodzą się oni przecież w świecie społecznym, a więc naturalnie przyjmują za własne pewną liczbę niewypowiedzianych na głos postulatów i pewników, chociażby o wprowadzaniu porządku społecznego skonstruowanego przez osoby pełnosprawne. Pozwala to przypuszczać, że praktyki terapeutów będą bardzo zbliżone. Terapeuci - jako aktorzy o w miarę spójnych i jednorodnych charakterystycznych dla całej kategorii społecznej cechach, mający podobne habitusy i jeden cel - rehabilitację - będą mieć podobne oczekiwania, postawy i działania wobec osób autystycznych. Praktyki te nie będą 
identyczne, chociażby ze względu na fakt habitusu, który jest tylko dyspozycją, a nie gwarantem określonego zachowania.

Terapeuci osób autystycznych, mając pewne dyspozycje (habitus, doksa, kapitał, por. Bourdieu, Wacquant 2001; Bourdieu 2004, 2006, 2008) do postrzegania osób z niepełnosprawnością jako niezaradnych, potrzebujących wsparcia, niesamodzielnych, „nieprzydatnych” społecznie, „innych”, niezrozumiałych, agresywnych, ze względu na ich niższy kapitał ekonomiczny, kulturowy, społeczny, symboliczny (por. Bourdieu, Wacquant 2001: 104), w ramach rehabilitacji, przyczyniają się do wypracowywania określonego porządku społecznego - utrwalania ich marginalizacji czy wykluczenia społecznego. Reprodukcja porządku społecznego w rehabilitacji polega na społecznej i kulturowej dominacji „typowych" terapeutów.

Rehabilitacja oparta na teorii Pierre’a Bourdieu stanowi obszar walki z innością osób niepełnosprawnych i dopasowaniem ich do norm charakterystycznych dla pełnosprawnego ogółu. Rehabilitacja osób autystycznych polega przede wszystkim na wdrażaniu ich do przestrzegania norm społecznych, uczeniu samodzielności i komunikacji, które umożliwią funkcjonowanie społeczne. Już w samej definicji położono nacisk na pracę "nad” osobą niepełnosprawną i przy jej „aktywnym uczestnictwie”, nie ma mowy natomiast o zmianie środowiska czy pracy „nad społeczeństwem” (Ustawa...). To niesie za sobą kolejne implikacje, ponieważ terapeuci mogą mieć przez to poczucie ważności swojej roli w procesie rehabilitacji, wzmacniane przez pozytywną ocenę społeczną tejże jako trudnej, a także odpowiedzialnej. To pozwala dominować terapeutom nad osobami autystycznymi i dokonywać przemocy symbolicznej na polu rehabilitacji, która nie jest interpretowana jako przemoc. Dyspozycje grupy dominującej (terapeutów) jawią się jako nienaznaczone, neutralne, uniwersalne, natomiast grupy zdominowanych (osób autystycznych) jako „różnice”, czyli negatywne znaki, braki, naznaczenia wymagające uzasadnienia oraz korekcji w ramach rehabilitacji. Na podstawie doksy, opinie o trudnych warunkach egzystencji tłumaczone są jako naturalne, autystycy bowiem dysponują niskim kapitałem społecznym i ekonomicznym.

Kapitał symboliczny zapewnia formę przewagi terapeutów, zakładającą zależność od tych, nad którymi pozwala dominować, czyli od osób autystycznych. Na kapitał symboliczny składają się między innymi pełnione funkcje, pozycja w nieformalnej hierarchii pola, ale i wszystkie świadectwa uznania społecznego, wszelkie formy bycia zauważanym, podziwianym (por. Bourdieu 2006: 236-237, 345; Jacyno 1997: 51, 111). W świetle przedstawionej teorii kapitał społeczny osób autystycznych jawi się jako ten charakteryzujący się nieużytecznością, niesprawnością, niespełnianiem kryteriów i norm, niepełnowartościowością, bezużytecznością. Osoba autystyczna jako „obywatel niewidzialny” (por. Raport... 2013) jawi się jako ta z najniższym kapitałem symbolicznym, bo jak można mówić o podziwianiu kogoś, kto nie jest zauważany (widzialny) w społeczeństwie?

Niebezpieczeństwo władzy terapeuty polega na tym, że podobnie jak

nauczyciel sprawuje tu najbardziej subtelną (a przez to niebezpieczną) z form władzy - mikrowładzę: rozproszoną i mało uchwytną władzę nad szczegółami, mikroelementami codziennego życia. W trakcie interakcji z uczniami mozolnie wykuwa - dzień po dniu, miesiąc po miesiącu - ich tożsamość: poczucie wyższości albo kompleks nieudacznika, orientację na współpracę albo na rywalizację, nawyk bycia szczerym albo pochwałę kłamstwa (gdy to się bardziej opłaca). Nauczyciel wchodzi przy tym w role Przedstawiciela Władzy (formalnej i moralnej): Sędziego (teoretycznie - ocenianie wiedzy i kwalifikacji, w praktyce - nagradzanie i karanie przejawiania się określonych form tożsamości), Kapłana (poprzez celebrowanie swojej władzy), Policjanta (kierowanie ruchem na dużej przerwie), Detektywa (kto rzucił 
ścierką w Zdzisia?), a nade wszystko Mędrca (ja wam to wszystko wyjaśnię), Aksjologa (ja wam powiem, jak powinno być) i Futurologa (ja wam powiem, jak z pewnością będzie) (Melosik, Szkudlarek 2009: 25).

Należy podkreślić - jak zauważa Zbigniew Kwieciński - że samo słowo „przemoc” wzbudza negatywne skojarzenia i oceny moralne, bo trudno uświadomić sobie możliwość użycia tego pojęcia w sposób neutralny. Ponadto mechanizm użycia przewagi i dominacji, autorytetu i przemocy może bowiem, nie tylko w skutkach, prowadzić do usprawiedliwienia (w oczach podmiotu) istniejących stosunków siły i nierówności, ale także sam z siebie być usprawiedliwiony wtedy, gdy ten przymus sprzyja korzystnym stanom rozwojowym jednostki i grup społecznych (Kwieciński 1995: 126).

Przemoc symboliczna ma wiele wymiarów i różne stopnie nasilenia, jej mechanizmy są zróżnicowane; z jednej strony prowadzi do nieuświadomionego podporządkowania jednostki wobec zastanych struktur i znaczeń oraz do podporządkowania jednostki wbrew i przeciwko jej potrzebom, interesom i możliwościom rozwojowym, a z drugiej strony niesie ze sobą doświadczenia prorozwojowe i może dostarczać instrumentów doświadczania podmiotowości. Przemoc symboliczna bowiem w tym wypadku nie tylko powoduje uwikłane ideologicznie sytuacje opresji wobec osoby autystycznej, ale może być czynnikiem walki z jej uprzedmiotowieniem.

Przemoc symboliczną można traktować jako

instrument adaptacji jednostki do norm grupy społecznej, do norm, reguł i przepisów organizacji w konwencjonalnym stadium rozwoju. Jednostka, przez system kar i nagród, ćwiczeń, narzucania znaczeń i uzasadnień istniejących norm, jest wćwiczana, wdrażana, przymusem wprowadzana w świat jej realnych i potencjalnych interakcji i relacji w zastanym świecie społecznym i jego instytucjonalnych urządzeń. Zarazem jednak od wczesnych okresów rozwoju narzucane są jednostce kulturowe interpretacje przyjętych definicji dobra i zła przez instytucje zastanej przez nią dominującej (w jej „przestrzeni życiowej”) religii. Tak więc i te nadrzędne - w danej, naturalnie zastanej i przekazywanej w procesach socjalizacji kulturze - kryteria wartościowania są narzucane jednostce za pośrednictwem przemocy symbolicznej pośredniczonej przez socjalizację (grup pierwotnych) i edukację (instytucji). Dopiero jednak rozwój jednostki do poziomu dyskursu znaczeń w obrębie uniwersum wartości wypracowanych w dziejach przez ludzkość i świadome kształtowanie przez jednostkę odrębnej, niepowtarzalnej tożsamości (jako symbolicznej struktury kompetencji zapewniającej ciągłość i swoistość osobowości społecznej w czasie i przestrzeni) jest taką fazą rozwoju, w której jednostka zyskuje pełnię kompetencji emancypacyjnych i komunikacyjnych, zdolność do kreowania siebie samej, swego świata społecznego i kultury (Kwieciński 1995: 127).

Ale czy i na ile jest to możliwe w przypadku osób autystycznych? Jakie one mają możliwości zdobyć „pełnię kompetencji emancypacyjnych”, w jakim stopniu komunikacyjnych? Należy pamiętać, że zaburzenie to składa się z następującej triady: odchyleń od normy w zakresie interakcji społecznych, komunikacji i aktywności. Gdyby jednak odwrócić sytuację i zadać pytanie, co by się stało, gdyby nie podejmowano żadnych prób wobec tej kategorii osób, by nauczyć je przestrzegania norm społecznych? Ten rodzaj przymusu zdaje się być usprawiedliwiony, gdy służy rozwojowi jednostki. W ten sposób Zbigniew Kwieciński wyróżnia dwie odmiany przemocy: rozwojową i nierozwojową (Kwieciński 1995: 126).

Dzieląc przemoc na rozwojową (usprawiedliwioną samą przez się) i nierozwojową (nieusprawiedliwioną), stajemy przed trudnymi pytaniami: 
1. Jaka i do czego odnoszona przemoc może być uznana za rozwojową, a jaka za nierozwojową? Jak jest granica sprzyjania-niesprzyjania rozwojowi jednostki?

2. Kto miałby definiować tę granicę oraz kryteria „sprzyjania rozwojowi”?

3. Jak rozumieć rozwój, jego wymiary, miary i kryteria? (Kwieciński 1995: 126).

Artykuł jest tylko próbą reinterpretacji kategorii przemocy symbolicznej w odniesieniu do rehabilitacji osób autystycznych, propozycją teoretyczną w badaniu tego procesu. Nie ulega jednak wątpliwości, że próba zmiany negatywnego nastawienia „typowych” osób wobec niepełnosprawnych jest cały czas nieskuteczna. Przyczyną tego stanu rzeczy jest zbyt mała świadomość społeczna istnienia przemocy symbolicznej.

\section{LITERATURA}

Barnes C., Mercer G. 2008, Niepełnosprawność, Wydawnictwo Sic!, Warszawa.

Bourdieu P. 2005, Dystynkcja. Społeczna krytyka władzy sądzenia, Wydawnictwo Naukowe Scholar, Warszawa.

Bourdieu P. 2006, Medytacje pascaliańskie, Oficyna Naukowa, Warszawa.

Bourdieu P. 2004, Męska dominacja, Oficyna Naukowa, Warszawa.

Bourdieu P. 2008, Zmysł praktyczny, Wydawnictwo Uniwersytetu Jagiellońskiego, Kraków.

Bourdieu P., Passeron J.-C. 1990, Reprodukcja. Elementy teorii systemu nauczania, Wydawnictwo Naukowe PWN, Warszawa.

Bourdieu P., Wacquant. L.J.D. 2001, Zaproszenie do socjologii refleksyjnej, Oficyna Naukowa, Warszawa.

Frith U. 2008, Autyzm. Wyjaśnienie tajemnicy, Gdańskie Wydawnictwo Psychologiczne, Gdańsk.

Gałkowski T. 2008, O potrzebie nowych badań nad autyzmem, w: Żyć z autyzmem. Dobro osoby z autyzmem - naukowe, społeczne i prawne aspekty rehabilitacji, red. M. Wlazły, Krajowe Towarzystwo Autyzmu Oddział w Szczecinie, Szczecin.

ICD-10 2008, Międzynarodowa Statystyczna Klasyfikacja Chorób i Problemów Zdrowotnych. Rewizja dziesiąta, t. I, World Health Organization, Centrum Systemów Informacyjnych Ochrony Zdrowia, http://www.csioz.gov.pl/src/files/klasyfikacje/ICD10Toml.pdf.

Jacyno M. 1997, Iluzje codzienności. O teorii socjologicznej Pierre’a Bourdieu, IFiS PAN, Warszawa.

Jaklewicz H. 1993, Autyzm wczesnodziecięcy. Diagnoza, przebieg, leczenie, Gdańskie Wydawnictwo Psychologiczne, Gdańsk.

Jastrząb J., Baczała D. 2011, Pedagogika Toruńska. Wybrane zagadnienia z pedagogiki korekcyjno-kompensacyjnej. Wzorzec terapeuty, Wydawnictwo Naukowe Uniwersytetu Mikołaja Kopernika, Toruń.

Kłoskowska A. 1990, Wstęp, w: Reprodukcja. Elementy teorii systemu nauczania, Wydawnictwo Naukowe PWN, Warszawa.

Kopciewicz L. 2007, Rodzaj i edukacja. Studium fenomenograficzne z zastosowaniem teorii społecznej Pierre'a Bourdieu, Wydawnictwo Naukowe Dolnośląskiej Szkoły Wyższej Edukacji TWP, Wrocław. 
Kossewska J., Społeczeństwo wobec osób niepełnosprawnych - postawy i ich determinanty, http://www.wsp.krakow.pl/biblio/pliki/kossewska_01.html.

Kozłowski J. 2008, Zachowania trudne u osób z zaburzeniami rozwojowymi: behawioralny model diagnozy, terapii i profilaktyki, w: Wybrane formy terapii i rehabilitacji osób z autyzmem, red. E. Pisuli, D. Danielewicz, Oficyna Wydawnicza Impuls, Kraków.

Kwieciński Z. 1995, Socjopatologia edukacji, Trans Humana, Olecko.

Melosik Z., Szkudlarek T. 2009, Kultura, tożsamość i edukacja. Migotanie znaczeń, Oficyna Wydawnicza Impuls, Kraków.

Pisula E. 2005, Małe dziecko z autyzmem, Gdańskie Wydawnictwo Psychologiczne, Gdańsk.

Pisula E. 2008, Efektywność działań terapeutycznych podejmowanych wobec dzieciz autyzmem, w: Wybrane formy terapii i rehabilitacji osób z autyzmem, red. E. Pisula, D. Danielewicz, Oficyna Wydawnicza Impuls, Kraków.

Proaktywne kierowanie trudnymi zachowaniami. Strategie i wskazówki dla członków personelu 2004, „Autica. Materiały na temat autyzmu”, z. 1.

Raport 2004, Sytuacja dorosłych osób z autyzmem w Polsce, Fundacja SYNAPSIS, Warszawa.

Raport 2013. Autyzm - Sytuacja Dorosłych, http://autyzmwpolsce.pl/pliki/Raport_2013_ Autyzm.pdf.

Smith D.D. 2009, Pedagogika specjalna. Podręcznik akademicki, t. 1, red. A. Firkowska-Mankiewicz, G. Szumski, Wydawnictwo Naukowe PWN, Warszawa.

Thomassin R. 2004, Autism Europe, w: Raport 2008. Sytuacja osób z autyzmem w województwie zachodniopomorskim, Krajowe Towarzystwo Autyzmu Oddział w Szczecinie, Szczecin.

Ustawa o rehabilitacji zawodowej i społecznej oraz zatrudnianiu osób niepełnosprawnych z 27 sierpnia 1997 r., Dz.U. 1997, nr 123, poz. 776.

Wapiennik E., Piotrowicz R. 2002, Niepełnosprawny - pełnoprawny obywatel Europy, Urząd Komitetu Integracji Europejskiej, Warszawa, http://idn.org.pl/tzchm-warszawa/grafika/ sprawny.pdf.

Woźniak Z. 2008, Niepełnosprawność i niepełnosprawni w polityce społecznej - społeczny kontekst medycznego problemu, Wydawnictwo SWPS Academica, Warszawa.

Zawody regulowane tzw. systemu ogólnego, w: Regulowane zawody i działalności w rzeczypospolitej polskiej. Opis wymagań kwalifikacyjnych, Ministerstwo Nauki i Szkolnictwa Wyższego, http://www.nauka.gov.pl/g2/oryginal/2013_05/2fc90959252ab275bd526f025471 8d89. pdf.

Żółkowska T. 2004, Wyrównywanie szans społecznych osób z niepełnosprawnością intelektualną. Uwarunkowania i obszary, Oficyna In Plus, Szczecin. 


\section{KEYWORDS}

AUTISM, REHABILITATION, SYMBOLIC VIOLENCE
SUMMARY This study is the attempt of the description of the symbolic violence serving the reproduction of the social structure in the rehabilitation of autistic persons. The starting point of this analysis is the thesis that people without disabilities act and think in an „oppressive" towards people with disabilities, however, are not always aware of this. The same therapists use symbolic violence against disabled persons, including autism. Symbolic violence is fundamentally the imposition of categories of thought and perception upon dominated social agents who then take the social order to be just. It is the incorporation of unconscious structures that tend to perpetuate the structures of action of the dominant. The dominated then take their position to be „right”. Symbolic violence is in some senses much more powerful than physical violence in that it is embedded in the very modes of action and structures of cognition of individuals, and imposes the spectre of legitimacy of the social order. 

